${ }^{1}$ Family Medicine Department. American University of Beirut Medical Center. Beirut. Lebanon. ${ }^{2}$ Dermatology Department. American University of Beirut Medical Center. Beirut, Lebanon.

This work had no financial support.

Recibido el 10 de abril de 2016, aceptado el 4 de agosto de 2016 .

Corresponding author: Malak H. Wehbe American University of Beirut Hospital.

P.O. Box: 11-0236- Family Medicine Department. Riad EI

Solh, Beirut:1107-2020. Lebanon-Beirut., fax number: 00-961-1-371 123, tel: 00-9611-350000, Ext: 3044. Mob: +9617010 6034

dr_malakwehbe@hotmail.com

\section{Confluent and reticulated papillomatosis subsiding spontaneously after delivery. Report of one case}

\author{
JINAN A.R. USTA ${ }^{1}$, SAMER GHOSN ${ }^{2}$, MALAK H. WEHBE ${ }^{1}$
}

\begin{abstract}
Gougerot and Carteaud confluent and reticulated papillomatosis (CARP) is an uncommon dermatosis characterized by hyperpigmented scaly macules or papillomatous papules coalescing into confluent patches or plaques centrally with a reticular pattern peripherally. We report a 28-year-old woman presenting at 16 weeks of gestation with an itchy rash that was biopsied and turned out to be consistent with CARP. Options for treatment were discussed but the woman refused to take any systemic therapy and used only moisturizers throughout her pregnancy. The rash subsided spontaneously after delivery.
\end{abstract}

(Rev Med Chile 2016; 144: 1494-1496)

Key words: Papilloma; Pregnancy; Remission, Spontaneous.

\section{Papilomatosis confluente y reticulada que remite espontáneamente después del parto. Informe de un caso}

La papilomatosis confluente y reticulada de Gougerot and Carteaud es una dermatosis infrecuente caracterizada por máculas escamosas hiperpigmentadas o pápulas papilomatosas que derivan en placas confluentes que tienen un patrón reticular en la periferia. Presentamos una mujer de 28 años con un embarazo de 16 semanas con un eritema cutáneo pruriginoso que fue biopsiado y cuya anatomía patológica fue compatible con el diagnóstico de papilomatosis confluente y reticulada. La paciente declinó cualquier tratamiento sistémico y sólo usó humectante durante el embarazo. El eritema cedió espontáneamente después del parto.

\section{A}

28-year-old woman G1P0A0 presented at 16 weeks of pregnancy with a new-onset mildly pruritic rash over the back and axillary areas that manifested several days prior to presentation. She denied history of previous similar episodes or recent sun exposure or the use of a new soap, cream or deodorant. Her past medical history was negative. Her medication intake included only supplemental iron during pregnancy.

Physical examination revealed brownish pat- ches with fine scaling exhibiting a characteristic reticulated pattern in the axillary vaults symmetrically and a more confluent pattern toward the center of the upper back (Figure 1). A skin biopsy from lesional skin revealed compact hyperkeratosis, focal parakeratosis, mild papillomatosis, epidermal hyperplasia, and a sparse superficial perivascular lymphocytic infiltrate. In view of the clinical and histopathological picture, the diagnosis of confluent and reticulated papillomatosis of Gourgerot and Carteaud was made. Considering 


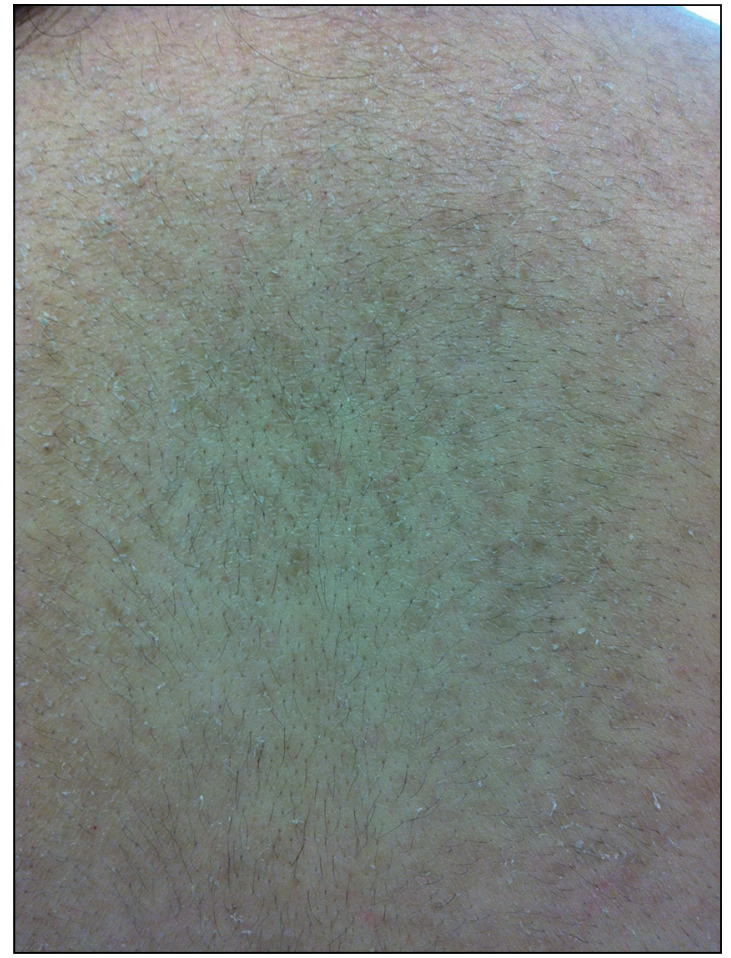

Figure 1. Axillary rash on presentation.

her pregnancy status, she elected not to use any systemic therapy and preferred the use of a moisturizer cream to alleviate the itching.

Her last month of pregnancy was complicated by gestational diabetes controlled on diet, gestational hypertension, and cholestasis. She went into spontaneous labor at 35 weeks and had an uncomplicated vaginal delivery of a normal newborn girl. The rash persisted during her pregnancy but regressed spontaneously and disappeared completely one week post-delivery (Figure 2). On a follow-up visit 40 days postpartum, she was still in remission. To the best of our knowledge, this is the first report of confluent and reticulated papillomatosis that became manifest during pregnancy and resolved completely and spontaneously after delivery.

\section{Discussion}

Confluent and reticulated papillomatosis (CRP) is a relatively rare skin disorder with unknown frequency and of unknown pathogenesis,

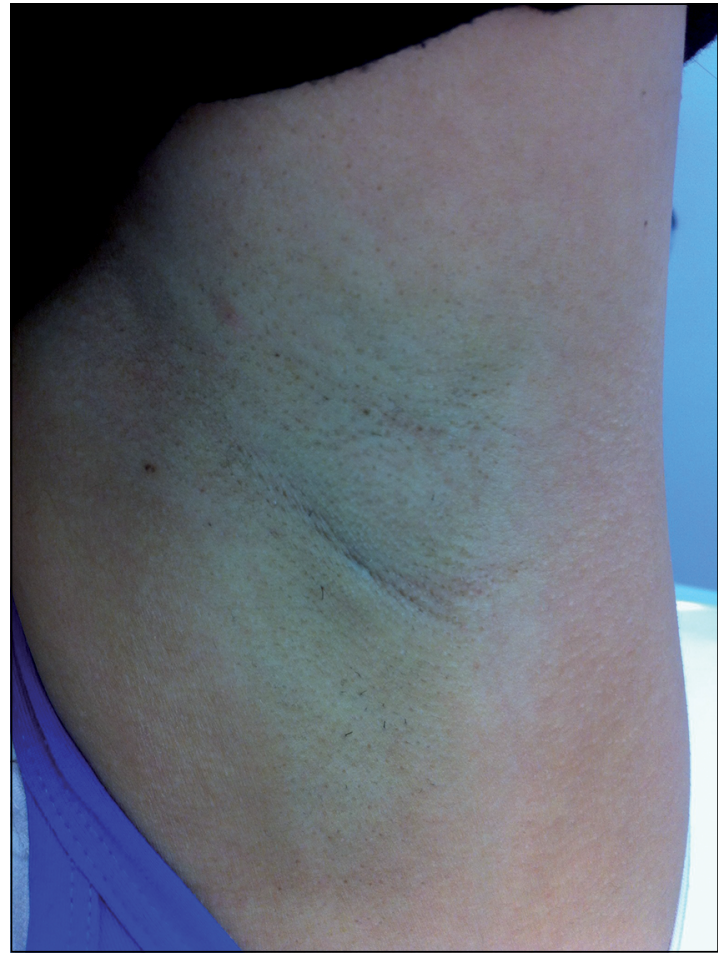

Figure 2. Resolution of rash on follow up visit, axillary vault.

but genetic susceptibility may play a role, since familial cases have been reported ${ }^{1}$. The disease occurs predominantly in young people, but can occur at any age, and in both sexes ${ }^{2}$. CRP manifests as grayish-brown, hyperkeratotic papules and plaques that form a reticular pattern peripherally and confluent plaques centrally. In most cases the rash is asymptomatic, but can be mildly pruritic ${ }^{3}$.

The condition has been associated with endocrine abnormalities like hyperthyroidism ${ }^{4}$, polycystic ovary syndrome ${ }^{5}$, obesity, abnormal glucose intolerance and hyperinsulinemia ${ }^{6}$; and with ultraviolet light exposure. One theory considers CRP a disorder of keratinocyte differentiation and maturation. This is supported by findings from electron microscopy studies and immune histochemical analysis ${ }^{7}$; along with reports of CRP improvement on topical analogues of vitamin $\mathrm{D}^{8}$. Another theory speculates CRP to be resulting from an abnormal host reaction to fungal infection. However, one study showed that $75 \%$ of cases had negative $\mathrm{KOH}$ staining, implying that fungi are probably not involved in the pathoge- 
nesis. Bacterial pathogens like Dietzia strains have been also implicated, supported by good response to antibiotics ${ }^{3,9,10}$. However, the effectiveness of certain antibiotics was argued to be due to their anti-inflammatory and anti-proliferative actions.

Several modalities of treatment have been reported. Oral antibiotics are the most consistently effective treatment ${ }^{10}$. Minocycline is considered as first line, but is considered category $\mathrm{D}$ and not recommended in pregnancy. Azythromycin, erythromycin, fucidic acid, tetracycline and cefdinir as well as topical mupirocin were also reported to be effective ${ }^{3,11}$. Other kinds of treatment reported to be successful include keratolytics, retinoids, vitamin D analogues, oral contraceptives, propylthiouracil, sodium thiosulphate, ammoniated mercury, thyroid extract, ultraviolet light, propylene glycol, antimycotics, and 70\% alcohol. However spontaneous resolution was not found to be an alternative outcome among the cases reviewed ${ }^{3,12}$

CRP in the case reported started in the second trimester of pregnancy and resolved spontaneously after delivery. This may be consistent with CRP being a host response, manifesting as an abnormal keratinization of the skin, to some of the endocrine changes occurring in pregnancy. The presence of gestational diabetes and hypertension favors an insulin resistance state that subsided postpartum; consistent with the finding that the degree of insulin resistance rapidly abates following delivery ${ }^{13}$. In conclusion, this is the first report of a case of CRP occurring in pregnancy and having a spontaneous remission, suggesting that CRP is actually a skin reaction to endocrine changes that can subside spontaneously after resolution of the precipitating factors. The spontaneous resolution of the condition raises doubts about the effectiveness of the various modalities of treatment as the condition could have resolved on its own.

\section{References}

1. Inalöz HS, Patel GK, Knight AG. Familial confluent and reticulated papillomatosis. Archives of Dermatology 2002; 138 (2): 276-7.

2. Scheinfeld N. Confluent and reticulated papillomatosis: a review of the literature. American Journal of Clinical Dermatology 2006; 7 (5): 305-13. Review.
3. Davis MD, Weenig RH, Camilleri MJ. Confluent and reticulate papillomatosis (Gougerot-Carteaud syndrome): a minocycline-responsive dermatosis without evidence for yeast in pathogenesis. A study of 39 patients and a proposal of diagnostic criteria. British Journal of Dermatology 2006; 154 (2): 287-93.

4. Zhang CH, Zhang C, Wu J, Shan SJ, Liu QZ, Fu Z, Chen HD. Confluent and reticulated papillomatosis associated with hyperthyroidism. European Journal of Dermatology 2010; 20 (6): 833-5.

5. Ozdemir S, Ozdemir M, Toy HJ. Confluent and reticulated papillomatosis associated with polycystic ovary syndrome treated with a combined contraceptive containing drospirenone. Journal of the European Academy of Dermatology and Venereology 2009; 23 (3): 358-9.

6. Hirokawa M, Matsumoto M, Iizuka H. Confluent and reticulated papillomatosis: a case with concurrent acanthosis nigricans associated with obesity and insulin resistance. Dermatology 1994; 188: 148-51.

7. Lee SH, Choi EH, Lee WS, Kang WH, Bang DS. Confluent and reticulated papillomatosis: a clinical, histopathological, and electron microscopic study. Journal of Dermatology 1991; 18 (12): 725-30.

8. Ginarte M, Fabeiro JM, Toribio J. Confluent and reticulated papillomatosis (Gougerot-Carteaud) successfully treated with tacalcitol. Journal of Dermatological Treatment 2002; 13 (1): 27-30.

9. Natarajan S, Milne D, Jones AL, Goodfellow M, Perry J, Koerner RJ. Dietzia strain X: a newly described Actinomycete isolated from confluent and reticulated papillomatosis. British Journal of Dermatology 2005; 153 (4): 825-7.

10. Jang HS, Oh CK, Cha JH, Cho SH, Kwon KS. Six cases of confluent and reticulated papillomatosis alleviated by various antibiotics. Journal of the American Academy of Dermatology 2001; 44 (4): 652-5. Review.

11. Gönül M, Cakmak SK, Soylu S, Kiliç A, Gül U, Ergül G. Successful treatment of confluent and reticulated papillomatosis with topical mupirocin. Journal of European Academy of Dermatology and Venereology 2008; 22 (9): 1140-2.

12. Tamraz H, Raffoul M, Kurban M, Kibbi AG, Abbas O. Confluent and reticulated papillomatosis: clinical and histopathological study of 10 cases from Lebanon. Journal of the European Academy of Dermatology and Venereology. 2013; 27 (1): e119-23.

13. Buchanan TA, Xiang AH. Gestational Diabetes Mellitus. Journal of Clinical Investigation 2005; 115: 485-91. doi: 10.1172/JCI24531. 